\title{
Ruthenium polypyridyl complexes containing the bischelating ligand 2,2'-azobispyridine. Synthesis, characterization and crystal structures
}

\author{
Eva Corral ${ }^{\mathrm{a}}$, Anna C.G. Hotze ${ }^{\mathrm{a}}$, Duncan M. Tooke ${ }^{\mathrm{b}}$, Anthony L. Spek ${ }^{\mathrm{b}}$, Jan Reedijk ${ }^{\mathrm{a}, *}$ \\ ${ }^{a}$ Leiden Institute of Chemistry, Gorlaeus Laboratories, Leiden University, P.O. Box 9502, 2300 RA Leiden, The Netherlands \\ ${ }^{\mathrm{b}}$ Department of Crystal and Structural Chemistry, Bijvoet Center for Biomolecular Research, Utrecht University, Padualaan 8 , \\ 3584 CH Utrecht, The Netherlands
}

Received 23 March 2005; accepted 11 May 2005

Available online 14 July 2005

Ruthenium and Osmium Chemistry Topical Issue.

\begin{abstract}
Three ruthenium polypyridyl compounds of structural formula $\left[\mathrm{Ru}(\mathrm{apy})(\mathrm{tpy}) \mathrm{L}^{n-}\right]\left(\mathrm{ClO}_{4}\right)_{(2-n)}\left(\right.$ apy $=2,2^{\prime}$-azobispyridine; tpy $=2,2^{\prime}: 6^{\prime}, 2^{\prime \prime}$-terpyridine; $\left.\mathrm{L}=\mathrm{Cl}, \mathrm{H}_{2} \mathrm{O}, \mathrm{CH}_{3} \mathrm{CN}\right)(\mathbf{1 a}-\mathbf{c})$ were synthesized and crystallized. These complexes were fully characterized by means of $1 \mathrm{D}$ and $2 \mathrm{D}{ }^{1} \mathrm{H}$ NMR spectroscopy, as well as mass spectrometry and elemental analysis. Although in theory two isomers are possible, i.e. the one in which the central $\mathrm{N}$ atom in tpy is trans to the azo $\mathrm{N}$ in apy and the one in which the former is trans to the pyridine $\mathrm{N}$ in apy, in all cases only the latter was observed. The molecular structures of the compounds were elucidated by single-crystal X-ray diffraction.
\end{abstract}

(C) 2005 Elsevier B.V. All rights reserved.

Keywords: Ruthenium; Polypyridyl; X-ray structure; NMR; Antitumor agents

\section{Introduction}

Recently, a large interest has grown in ruthenium polypyridyl complexes as a possible alternative to the use of classical platinum chemotherapy [1]. Some examples of these compounds are $\mathrm{Ru}(\mathrm{tpy}) \mathrm{Cl}_{3}$ and $\alpha$ - $\left[\mathrm{Ru}(\text { azpy })_{2} \mathrm{Cl}_{2}\right] \quad$ (azpy $=2$-phenylazopyridine). $\mathrm{Ru}($ tpy $) \mathrm{Cl}_{3}$ shows a pronounced in vitro cytotoxicity and exhibits antitumor activity [2]. The compound $\alpha$-[Ru(azpy $\left.)_{2} \mathrm{Cl}_{2}\right]$ has been reported to show a remarkably high cytotoxicity, even more pronounced than cisplatin in most of the tested cell lines [3,4]. The increased amount of possible binding modes of ruthe-

\footnotetext{
* Corresponding author. Fax: +31 715274671.

E-mail address: reedijk@chem.leidenuniv.nl (J. Reedijk).
}

nium polypyridyl complexes to DNA as compared to those of the first generations of platinum drugs, including intercalation of the ligands between two parallel base pairs, could be crucial in order to overcome resistance to cisplatin [5]. In addition, a number of ruthenium complexes, such as NAMI-A, $\left[\mathrm{H}_{2} \mathrm{im}\right]\left[\right.$ trans $\left.-\mathrm{RuCl}_{4}(\mathrm{dmso}-\mathrm{S})(\mathrm{Him})\right] \quad(\mathrm{Him}=$ imidazole; dmso = dimethyl sulfoxide), have shown to display an antimetastatic activity, which has not been observed in the case of the routinely used platinum compounds $[6,7]$.

In this paper, the synthesis and characterization of a group of the above-mentioned ruthenium polypyridyl complexes are described. Taking $\mathrm{Ru}(\mathrm{tpy}) \mathrm{Cl}_{3}$ as the starting building block in the synthesis, the second moiety of choice is $2,2^{\prime}$-azobispyridine (apy), a didentate polypyridyl ligand. First described by Kirpal in 1927 [8], the 
availability of two possible coordination sites has made it attractive in the synthesis of multiple dinuclear complexes, most of which were symmetric, as reviewed by Kaim [9]. On the other hand apy is structurally related to 2-phenylazopyridine, azpy, a ligand present in the recently reported cytotoxic bis(2-phenylazo)pyridine ruthenium(II) compounds, such as the above-mentioned $\alpha-\left[\mathrm{Ru}(\text { azpy })_{2} \mathrm{Cl}_{2}\right][3,4]$.

In addition, the electronic distribution allows for the occurrence of metal-to-metal electron transfer. This property makes this ligand interesting in subjects such as electrochemistry and catalysis. In that last field, a few compounds that respond to the formula $\left[\mathrm{Ru}(\text { tpy) } \mathrm{LCl}]^{n+}\right.$, where $\mathrm{L}$ is a didentate ligand have been synthesized in regard to their interesting catalytic potential, as precursors of oxo-ruthenium complexes [10-12].

The X-ray structures of the three newly prepared complexes are presented, which provide interesting observations by comparison with each other, as well as with other already reported related structures $[10,11,13,14]$. These results indicate a powerful possibility to tune the sixth coordination site and tailor-make complexes that display varying properties, thereby fulfilling different requirements.

\section{Experimental}

\subsection{Materials and reagents}

$2,2^{\prime}$-Azobispyridine (apy) and $\mathrm{Ru}(\mathrm{tpy}) \mathrm{Cl}_{3}$ were synthesized according to the literature methods $[8,15]$. LiCl, $\mathrm{NaClO}_{4}$ (both Merck), $\mathrm{NaClO}, \mathrm{AgNO}_{3}$, (both Acros), terpy (Aldrich) and $\mathrm{RuCl}_{3} \cdot 3 \mathrm{H}_{2} \mathrm{O}$ (Johnson \& Matthey) were used as supplied. All other chemicals and solvents were reagent grade commercial materials and used as received, without further purification.

\subsection{Physical measurements}

$\mathrm{C}, \mathrm{H}$ and $\mathrm{N}$ determinations were performed on a Perkin Elmer 2400 Series II analyzer. Mass spectra were obtained with a Finnigan MAT TSQ-700 mass spectrometer equipped with a custom-made electrospray interface (ESI). FTIR spectra were obtained on a Perkin Elmer Paragon 1000 FTIR spectrophotometer equipped with a Golden Gate ATR device, using the diffuse reflectance technique (res. $4 \mathrm{~cm}^{-1}$ ). NMR spectra were recorded on a Bruker DPX-300 spectrometer operating at a frequency of $300 \mathrm{MHz}$. Chemical shifts were calibrated against tetramethylsilane (TMS).

\subsection{X-ray structural determination}

X-ray intensities were measured on a Nonius Kappa$\mathrm{CCD}$ diffractometer with rotating anode and $\mathrm{Mo} \mathrm{K} \alpha$ radiation (graphite monochromator, $\lambda=0.71073 \AA$ ) at a temperature of $150(2) \mathrm{K}$. A multi-scan absorption correction was applied using MULABS [16] (1a) or SADABS [17] (1b and 1c). The structures were solved with the program DIRDIF [18], and refined using the program SHELXL-97 [19] against $F^{2}$ of all reflections up to a resolution of $(\sin \theta / \lambda)_{\max }=0.65$. The perchlorate anion containing $\mathrm{Cl}(2)$ in $\mathbf{1 b}$ was refined using a disorder model, with final occupancies of $88 \%$ and $12 \%$. All other non-hydrogen atoms were freely refined with anisotropic displacement parameters. The $\mathrm{H}$ atoms on the water molecules in $\mathbf{1 b}$ were found in a difference map and refined with isotropic displacement parameters. All other $\mathrm{H}$ atoms were placed in geometrically idealized positions $[d(\mathrm{C}-\mathrm{H})=0.98 \AA$ for methyl $\mathrm{H}$ atoms and $0.95 \AA$ for other $\mathrm{H}$ atoms] and constrained to ride on their parent atoms, with $U_{\text {iso }}(\mathrm{H})=1.5 U_{\text {eq }}(\mathrm{C})$ for methyl $\mathrm{H}$ atoms and $U_{\text {iso }}(\mathrm{H})=1.2 U_{\text {eq }}(\mathrm{C})$ for all other $\mathrm{H}$ atoms. The structure calculations, space group determination, validation and drawings were performed with the program PLATON [20]. Further experimental details are given in Table 1.

\subsection{Synthesis and characterization of the $\left[\mathrm{Ru}(\mathrm{apy})(\mathrm{tpy}) \mathrm{L}^{n-}\right]\left(\mathrm{ClO}_{4}\right)_{(2-n)}$ compounds}

The synthesis of the three complexes was accomplished in three steps, analogously to the synthesis of their related azpy complexes [10], as depicted in Scheme 1 and described in detail below.

Caution: Although no problems were encountered in the synthesis and handling of the materials described below, those containing perchlorate are potentially explosive and should be handled with care. 2.4.1. Chloro $\left(2,2^{\prime}\right.$-azobispyridine $)\left(2,2^{\prime}: 6^{\prime}, 2^{\prime \prime}\right.$-terpyridine $)$ -
ruthenium(II) perchlorate, [ $\mathrm{Ru}($ apy $)($ tpy $) \mathrm{Cl}]\left(\mathrm{ClO}_{4}\right)$
(1a)
$\mathrm{LiCl}(300 \mathrm{mg}, 7.08 \mathrm{mmol})$ was dissolved in $45 \mathrm{ml}$ of ethanol:water (3:1). Triethylamine $(0.096 \mathrm{ml}$, $0.68 \mathrm{mmol}$ ) was added, followed by $\mathrm{Ru}(\mathrm{tpy}) \mathrm{Cl}_{3} \cdot 3 \mathrm{H}_{2} \mathrm{O}$ (300 $\mathrm{mg}, \quad 0.68 \mathrm{mmol}$ ) and 2,2'-azobispyridine (apy; $189 \mathrm{mg}, 1.02 \mathrm{mmol}$ ). The mixture was refluxed for one hour, after which the hot solution was filtered to remove any insoluble material. The filtrate was left to cool down to RT. By addition of a saturated aqueous solution of $\mathrm{NaClO}_{4}(15 \mathrm{ml})$, a dark crystalline solid appeared. The crystals obtained were found to be suitable for X-ray diffraction measurements. The product was collected by filtration, washed with little ice-cold water and dried in vacuo over $\mathrm{P}_{4} \mathrm{O}_{10}$. Yield: $211 \mathrm{mg}(47 \%)$. Anal. Calc. for $\mathrm{C}_{25} \mathrm{H}_{19} \mathrm{~N}_{7} \mathrm{O}_{4} \mathrm{Cl}_{2} \mathrm{Ru}$ : C, 45.9; H, 2.9; N, 15.0. Found: $\mathrm{C}, \quad 45.2 ; \mathrm{H}, 2.9 ; \mathrm{N}, 14.8 \% . \mathrm{m} / \mathrm{z}$ (ESIMS) 553.0 ([Ru(apy)(tpy)Cl $\left.]^{+}, 100 \%\right) .{ }^{1} \mathrm{H}$ NMR (DMSO- $\left.d_{6}\right): \delta$ (ppm): $9.83(1 \mathrm{H}, \mathrm{d}, 4.61 \mathrm{~Hz}) ; 8.93(1 \mathrm{H}, \mathrm{d}, 7.90 \mathrm{~Hz})$; $8.63(3 \mathrm{H}, \mathrm{m}) ; 8.45(1 \mathrm{H}, \mathrm{t}, 7.86 \mathrm{~Hz}) ; 8.27(2 \mathrm{H}, \mathrm{m}) ; 8.10$ 
Table 1

Crystal data and structure refinement details for $[\mathrm{Ru}($ apy $)(\mathrm{tpy}) \mathrm{Cl}]\left(\mathrm{ClO}_{4}\right)$ $\left[\mathrm{Ru}(\mathrm{apy})(\mathrm{tpy})\left(\mathrm{CH}_{3} \mathrm{CN}\right)\right]\left(\mathrm{ClO}_{4}\right)_{2}(\mathbf{1 c})$

\begin{tabular}{|c|c|c|c|}
\hline & 1a & 1b & $1 \mathrm{c}$ \\
\hline Formula & $\mathrm{C}_{25} \mathrm{H}_{19} \mathrm{~N}_{7} \mathrm{O}_{4} \mathrm{RuCl}_{2}$ & $\mathrm{C}_{25} \mathrm{H}_{25} \mathrm{~N}_{7} \mathrm{O}_{11} \mathrm{RuCl}_{2}$ & $\mathrm{C}_{27} \mathrm{H}_{22} \mathrm{~N}_{8} \mathrm{O}_{8} \mathrm{RuCl}_{2}$ \\
\hline Formula weight & 653.44 & 771.49 & 758.50 \\
\hline Crystal color & dark (purple) & dark (purple) & dark (purple) \\
\hline Crystal size (mm) & $0.08 \times 0.20 \times 0.23$ & $0.03 \times 0.09 \times 0.24$ & $0.15 \times 0.20 \times 0.30$ \\
\hline Crystal system & monoclinic & triclinic & triclinic \\
\hline Space group & $P c($ No.7) & $P \overline{1}($ No. 2$)$ & $P \overline{1}($ No. 2$)$ \\
\hline$a(\AA)$ & $8.6951(5)$ & $10.9876(9)$ & $11.2566(7)$ \\
\hline$b(\AA)$ & $9.8750(5)$ & $11.5675(5)$ & $11.6870(8)$ \\
\hline$c(\AA)$ & $14.7384(7)$ & $12.8188(15)$ & $12.0681(9)$ \\
\hline$\alpha\left(^{\circ}\right)$ & 90 & $79.141(7)$ & $94.444(6)$ \\
\hline$\beta\left({ }^{\circ}\right)$ & $97.810(4)$ & $70.879(7)$ & $113.183(5)$ \\
\hline$\gamma\left({ }^{\circ}\right)$ & 90 & $84.259(6)$ & $91.415(5)$ \\
\hline$V\left(\AA^{3}\right)$ & $1253.76(11)$ & $1510.5(2)$ & $1452.40(18)$ \\
\hline$Z$ & 2 & 2 & 2 \\
\hline$D_{\text {calc }}\left(\mathrm{g} / \mathrm{cm}^{3}\right)$ & 1.731 & 1.696 & 1.734 \\
\hline$\mu(\operatorname{Mo~K} \alpha)\left(\mathrm{mm}^{-1}\right)$ & 0.887 & 0.767 & 0.790 \\
\hline Transmission range & $0.63-0.93$ & $0.76-0.98$ & $0.72-0.89$ \\
\hline Total/unique reflections & $33311 / 5711$ & $41476 / 6905$ & $40042 / 6634$ \\
\hline$R_{1}$ & 0.0316 & 0.0379 & 0.0289 \\
\hline$\omega \mathbf{R}^{2}$ & 0.0785 & 0.0825 & 0.0688 \\
\hline$S$ & 1.041 & 1.03 & 1.043 \\
\hline$N_{\text {par }}$ & 352 & 485 & 416 \\
\hline Residual density $\left(\mathrm{e} / \AA^{3}\right)$ & $-0.49 / 1.14$ & $-0.63 / 1.56$ & $-0.80 / 1.03$ \\
\hline
\end{tabular}<smiles>O=[N+]([O-])O[Na]</smiles>

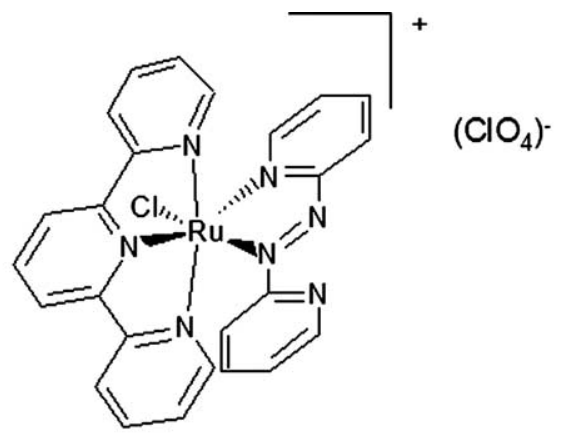

$1 a$

1) $\mathrm{AgNO}_{3}$ acetone, $\mathrm{H}_{2} \mathrm{O}$ 2) $\mathrm{NaClO}_{4}$
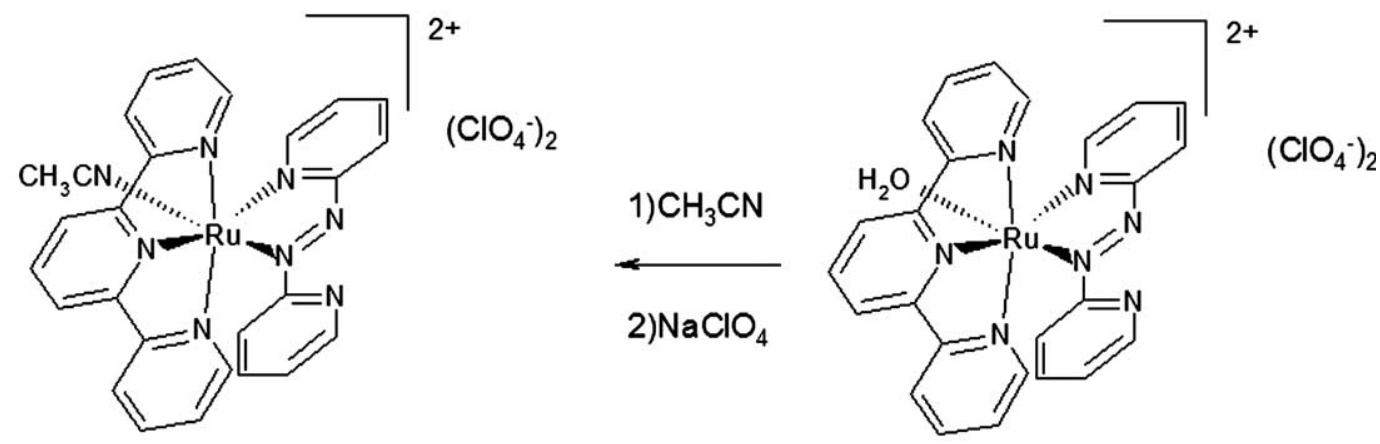

$1 \mathbf{c}$

1b

Scheme 1. Synthesis of the $\left[\mathrm{Ru}(\right.$ apy $)\left(\right.$ tpy) $\left.\mathrm{L}^{n-}\right]\left(\mathrm{ClO}_{4}\right)_{(2-n)}$ compounds. 
$(2 \mathrm{H}, \mathrm{t}, 6.57 \mathrm{~Hz}) ; 7.82(1 \mathrm{H}, \mathrm{d}, 3.57 \mathrm{~Hz}) ; 7.72(1 \mathrm{H}, \mathrm{t}$, $7.71 \mathrm{~Hz}) ; 7.41(2 \mathrm{H}, \mathrm{t}, 6.09 \mathrm{~Hz}) ; 7.31(1 \mathrm{H}, \mathrm{t}, 4.72 \mathrm{~Hz})$; $7.22(2 \mathrm{H}, \mathrm{d}, 4.46 \mathrm{~Hz}) ; 7.12(1 \mathrm{H}, \mathrm{d}, 8.07 \mathrm{~Hz})$.

2.4.2. Aqua (2,2'-azobispyridine $)\left(2,2^{\prime}: 6^{\prime}, 2^{\prime \prime}\right.$ terpyridine $)$ ruthenium(II) diperchlorate dihydrate, [Ru(apy)(tpy)$\left.\left(\mathrm{H}_{2} \mathrm{O}\right)\right]\left(\mathrm{ClO}_{4}\right)_{2} \cdot 2 \mathrm{H}_{2} \mathrm{O}(\mathbf{l b})$

To a stirred solution of $[\mathrm{Ru}($ apy $)($ tpy $) \mathrm{Cl}]\left(\mathrm{ClO}_{4}\right)$ (170 mg, $0.26 \mathrm{mmol})$ in $30 \mathrm{ml}$ of acetone:water (1:5), 1 equiv. of $\mathrm{AgNO}_{3}$ (44 mg, $\left.0.26 \mathrm{mmol}\right)$ was added. The mixture was refluxed for one hour, then left to cool down to RT. Any possible rests of unreacted starting material and $\mathrm{AgCl}$ were filtered off. Finally a saturated aqueous solution of $\mathrm{NaClO}_{4}(10 \mathrm{ml})$ was added and the solution was left overnight at $4{ }^{\circ} \mathrm{C}$. The product was collected by filtration, washed with little ice-cold water and dried in vacuo over $\mathrm{P}_{4} \mathrm{O}_{10}$. Yield: $153 \mathrm{mg}$ (76\%). Anal. Calc. for $\mathrm{C}_{25} \mathrm{H}_{25} \mathrm{~N}_{7} \mathrm{O}_{11} \mathrm{Cl}_{2} \mathrm{Ru}$ : C, 38.9; $\mathrm{H}$, 3.3; N, 12.7. Found: C, 39.1; H, 3.0; N, 12.9\%. m/z (ESIMS) $259.2\left(\left[\mathrm{Ru}(\text { apy)(tpy) }]^{2+}, 100 \%\right) .{ }^{1} \mathrm{H} \quad \mathrm{NMR}\right.$ (DMSO- $\left.d_{6}\right): \delta(\mathrm{ppm}): 9.46(1 \mathrm{H}, \mathrm{d}, 5.11 \mathrm{~Hz}) ; 9.01(1 \mathrm{H}$, d, $7.82 \mathrm{~Hz}) ; 8.67(3 \mathrm{H}, \mathrm{m}) ; 8.55(1 \mathrm{H}, \mathrm{t}, 8.09 \mathrm{~Hz}) ; 8.36$ $(2 \mathrm{H}, \mathrm{m}) ; 8.19(2 \mathrm{H}, \mathrm{t}, 7.83 \mathrm{~Hz}) ; 7.84(1 \mathrm{H}, \mathrm{d}, 4.70 \mathrm{~Hz})$; $7.75(1 \mathrm{H}, \mathrm{t}, 7.67 \mathrm{~Hz}) ; 7.50(2 \mathrm{H}, \mathrm{m}) ; 7.34(3 \mathrm{H}, \mathrm{m}) ; 7.14$ $(1 \mathrm{H}, \mathrm{d}, 8.00 \mathrm{~Hz})$.

\subsubsection{Acetonitrile $\left(2,2^{\prime}\right.$-azobispyridine $)\left(2,2^{\prime}: 6^{\prime}, 2^{\prime \prime}\right.$ - terpyridine) ruthenium (II) diperchlorate, \\ $\left[\mathrm{Ru}(\right.$ apy $)($ tpy $\left.)\left(\mathrm{CH}_{3} \mathrm{CN}\right)\right]\left(\mathrm{ClO}_{4}\right)_{2}(\mathbf{1 c})$}

$\left[\mathrm{Ru}(\mathrm{apy})(\mathrm{tpy})\left(\mathrm{H}_{2} \mathrm{O}\right)\right]\left(\mathrm{ClO}_{4}\right)_{2}(56 \mathrm{mg}, 0.08 \mathrm{mmol})$ was dissolved in $9 \mathrm{ml} \mathrm{CH}_{3} \mathrm{CN}$. The solution was refluxed for $30 \mathrm{~min}$. The volume of the solution was reduced 5-6 times under reduced pressure before adding a saturated aqueous solution of $\mathrm{NaClO}_{4}(2.8 \mathrm{ml})$. A dark crystalline solid appeared overnight at $4{ }^{\circ} \mathrm{C}$, from which a single crystal suitable for $\mathrm{X}$-ray diffraction measurements was extracted. The product was collected by filtration, washed with little ice-cold water and dried in vacuo over $\mathrm{P}_{4} \mathrm{O}_{10}$. Yield: $45 \mathrm{mg}(78 \%)$. Anal. Calc. for $\mathrm{C}_{27} \mathrm{H}_{22} \mathrm{~N}_{8} \mathrm{O}_{8} \mathrm{Cl}_{2} \mathrm{Ru}$ : C, 42.8; H, 2.9; N, 14.8. Found: $\mathrm{C}, \quad$ !42.8; H, 2.9; No 15.0\%. $\mathrm{m} / z$ (ESIMS) 279.8 ([Ru(apy)-(tpy) $\left.\left.\left(\mathrm{CH}_{3} \mathrm{CN}\right)\right]^{2+}, \quad 100 \%\right) ; \quad 259.2$ ([Ru(apy) (tpy) $\left.]^{2+}, 30 \%\right) .{ }^{1} \mathrm{H}$ NMR $\left(\mathrm{CDCN}_{3}\right): \delta(\mathrm{ppm}): 9.67(1 \mathrm{H}$, d, $5.17 \mathrm{~Hz}) ; 8.93(1 \mathrm{H}, \quad \mathrm{d}, 7.91 \mathrm{~Hz}) ; 8.50(1 \mathrm{H}, \mathrm{t}$, $7.64 \mathrm{~Hz}) ; 8.38(3 \mathrm{H}, \mathrm{m}) ; 8.28(1 \mathrm{H}, \mathrm{m}) ; 8.18(1 \mathrm{H}, \mathrm{t}$, $6.00 \mathrm{~Hz}) ; 8.06(2 \mathrm{H}, \mathrm{t}, 9.16 \mathrm{~Hz}) ; 7.80(1 \mathrm{H}, \mathrm{d}, 3.66 \mathrm{~Hz})$; $7.70(1 \mathrm{H}, \mathrm{t}, 7.82 \mathrm{~Hz}) ; 7.36(4 \mathrm{H}, \mathrm{m}) ; 7.27(2 \mathrm{H}, \mathrm{m})$.

\section{Results and discussion}

\subsection{Synthesis and characterization of the} $\left[\mathrm{Ru}(\mathrm{apy})(\mathrm{tpy}) \mathrm{L}^{n-}\right]\left(\mathrm{ClO}_{4}\right)_{(2-n)}$ compounds

The synthesis of $[\mathrm{Ru}(\mathrm{apy})(\mathrm{tpy}) \mathrm{Cl}]\left(\mathrm{ClO}_{4}\right)$ takes place in a one-pot reaction from the previously synthesized
$\mathrm{Ru}(\mathrm{tpy}) \mathrm{Cl}_{3} \cdot 3 \mathrm{H}_{2} \mathrm{O}$ and $2,2^{\prime}$-azobispyridine (apy). The presence of both triethylamine and lithium chloride is needed. The first of these compounds acts as a reducing agent of $\mathrm{Ru}$ (III) to $\mathrm{Ru}(\mathrm{II})$, helping in the dissociation of the chloride from $\mathrm{Ru}(\mathrm{tpy}) \mathrm{Cl}_{3} \cdot 3 \mathrm{H}_{2} \mathrm{O}$, whereas $\mathrm{LiCl}$ is used to prevent any dissociation of $\mathrm{Cl}^{-}$from the product.

$\mathrm{AgNO}_{3}$ in an aqueous solution is required to substitute the chloro ligand, which is filtered off in the form of the insoluble salt $\mathrm{AgCl}$, by an aqua ligand. The latter is easily substituted by acetonitrile by simply refluxing for a short time in that solvent.

The possibility to synthesize a complex in which the sixth coordination position can be occupied by ligands with different lability, which also have an influence in the solubility, provides with a choice to fulfill the requirements of each situation. DNA is thought to be the ultimate target of antitumor-active ruthenium and platinum compounds [1]. The kinetics of the reaction of the complex with DNA are expected to be different in each case. Therefore the kinetics can be optimized by simply tuning the sixth coordination site.

Crystallization turned out to be the most appropriate method found for the purification of these three new compounds. For that purpose, perchlorate was found to be the ideal counter ion, which not only allowed obtaining the compounds in high purity, but also crystals suitable for X-ray diffraction analysis.

The composition and structures of these three complexes are confirmed by elemental analysis, mass spectrometry, infrared spectroscopy and ${ }^{1} \mathrm{H}$ NMR spectroscopy. The microanalytical data are consistent with the empirical formulas $\mathrm{C}_{25} \mathrm{H}_{19} \mathrm{~N}_{7} \mathrm{O}_{4} \mathrm{RuCl}_{2}$ (1a), $\mathrm{C}_{25} \mathrm{H}_{25} \mathrm{~N}_{7} \mathrm{O}_{11} \mathrm{RuCl}_{2}$ (1) and $\mathrm{C}_{27} \mathrm{H}_{22} \mathrm{~N}_{8} \mathrm{O}_{8} \mathrm{RuCl}_{2}$ (1c). The mass spectrum of 1a reveals the appearance of a molecular peak at $\mathrm{m} / \mathrm{z}$ (ESIMS) 553.0, which corresponds to the expected cation $\left[\mathrm{Ru}(\text { apy)(tpy) } \mathrm{Cl}]^{+}\right.$. In the case of $\mathbf{1 b}$ the aqua ligand is dissociated, therefore the molecular peak appears at $\mathrm{m} / z$ (ESIMS) 259.2, which corresponds to the species $[\mathrm{Ru}(\mathrm{apy})(\mathrm{tpy})]^{2+}$. This peak was also found in the case of 1c, however the molecular peak was found at $\mathrm{m} / \mathrm{z}$ (ESIMS) 279.8, corresponding to the cation $\left[\mathrm{Ru}(\mathrm{apy})(\mathrm{tpy})\left(\mathrm{CH}_{3} \mathrm{CN}\right)\right]^{2+}$.

The infrared spectra of the three complexes are almost identical. The only remarkable difference is the presence of a broad, weak peak at $3000-3500 \mathrm{~cm}^{-1}$ in the spectrum of $\mathbf{1 b}$, which appears not only as a consequence of the aqua ligand, but also of the water molecules in the lattice structure of the compound, as described in Section 3.2. The presence of perchlorate as a counterion is confirmed by the very strong, broad peak at $1070-1090 \mathrm{~cm}^{-1}$ and the strong, sharp peak at around $620 \mathrm{~cm}^{-1}$. Further the spectrum is complicated, with many peaks in the fingerprint area. A weak, broad peak around $3090 \mathrm{~cm}^{-1}$, characteristic of aromatic $\mathrm{C}-\mathrm{H}$ stretching, as well as a sharp peak of medium intensity 
around $1600 \mathrm{~cm}^{-1}$, characteristic of aromatic ring stretchings, and an intense, sharp peak at 765$767 \mathrm{~cm}^{-1}$, characteristic of ring deformations and $\mathrm{C}-\mathrm{H}$ out-of-plane deformations, appear as expected from a structure including aromatic rings. Two sharp peaks of medium intensity appear at 1448 and $1300 \mathrm{~cm}^{-1}$, respectively. These signals are the result of the $\mathrm{N}=\mathrm{N}$ stretching vibration, indicating the presence of an azo group in the molecule. A $\mathrm{Ru}-\mathrm{Cl}$ stretching mode would be expected [21] in the area around $300 \mathrm{~cm}^{-1}$. However, this is a too crowded area with bands therefore no conclusions can be drawn.

Finally, the solution geometry can be accurately assigned by means of $2 \mathrm{D}^{1} \mathrm{H}$ NMR spectroscopy. Together with the NOE couplings, the COSY couplings between the peaks unmistakably confirm that the central nitrogen atom in tpy is trans to the pyridine $\mathrm{N}$ in apy in the three complexes (see Section 3.3).

\subsection{X-ray structural determinations}

Plots of the structures of the cations of $\left[\mathrm{Ru}\left(\right.\right.$ apy) $($ tpy $\left.) \mathrm{L}^{n-}\right]\left(\mathrm{ClO}_{4}\right)_{(2-n)} \quad\left(\mathrm{L}=\mathrm{Cl}, \mathrm{H}_{2} \mathrm{O}, \mathrm{CH}_{3} \mathrm{CN}\right)$ are given in Fig. 1.

The ligand apy could theoretically yield two different isomers of $\left[\mathrm{Ru}(\mathrm{apy})(\mathrm{tpy}) \mathrm{L}^{n-}\right]^{(2-n)^{+}}$, the one in which the azo nitrogen of apy is trans to the pyridine nitrogen of terpy and the one in which the azo nitrogen is trans to the sixth coordination position, that is to say, to the chloro in $\mathbf{1 a}$, the aqua in $\mathbf{1 b}$ and the acetonitrile in $\mathbf{1 c}$. However, the only observed isomer is in all three cases the latter. A similar arrangement has been reported for the 2-phenylazopyridine (azpy) analogues [10,11,13].

$\mathrm{The} \mathrm{Ru}-\mathrm{N}(\mathrm{azo})$ bond distance is shorter than that of $\mathrm{Ru}-\mathrm{N}$ (pyridine) in all three cases (see Table 2). This result is consistent with the literature observations for the azpy analogues $[10,11,13]$ and can be explained by the stronger $\pi$-backbonding, $\mathrm{d} \pi(\mathrm{Ru}) \rightarrow \pi^{*}(\mathrm{azo})$. The bite angle of the apy ligand is between 76.2 (1a) and 76.8 (1b), comparable to the azpy ligand in $[\mathrm{Ru}($ azpy)(tpy)Cl]Cl [11]. The terpy ligand is coordinated in such a way that the distance between the ruthenium and the central $\mathrm{N}$ is shorter than the distances between the ruthenium and the extreme $\mathrm{N}$ atoms. This characteristic was also observed in the above-mentioned azpy analogues $[10,11,13]$, whereas in the starting complex $\mathrm{Ru}($ tpy $) \mathrm{Cl}_{3}$ these three bond lengths are equivalent [14]. Finally the terpy ligand is planar whereas the apy ligand is not. The latter consists of two planes: that of the coordinating pyridine ring and the one of the non-coordinating pyridine ring, which reduces the delocalization through the apy ligand. The dihedral angle between these two planes is $33.52(19)^{\circ}$ for $\mathbf{1 a}$, $32.52(16)^{\circ}$ for $\mathbf{1 b}$ and $53.56(10)^{\circ}$ in the case of $\mathbf{1 c}$.

\subsubsection{Packing in the crystal lattice}

Three-dimensional packing of the three complexes is depicted in Figs. 2-4. Hydrogen bonding plays an important role in the crystal structure of complex $\mathbf{1 b}$ (Fig. 3), the only one in which classical hydrogen bonds are formed. These occur between the hydrogen atoms of the aqua ligand and the oxygen atoms of both the water molecules and one perchlorate counter ion, between the hydrogen atoms of the water molecules and the oxygen atoms of perchlorate and also between the former and the oxygen atoms of other water molecules.

$\pi-\pi$ stacking is observed between the pyridine rings in all three complexes. In both $\mathbf{1 a}$ and $\mathbf{1 b}$ (Figs. 2 and 3), this stacking occurs between a pyridine ring of a terpy ligand and the opposite pyridine ring of the terpy ligand coordinated to the adjacent molecule, as well as between pyridine rings of adjacent apy ligands. Complex 1c only displays $\pi-\pi$ stacking between opposite terpy pyridine rings.

\section{3. ${ }^{1} \mathrm{H} N \mathrm{NMR}$ characterization of the $\left[\mathrm{Ru}(\right.$ apy $)($ tpy $\left.) L^{n-}\right]\left(\mathrm{ClO}_{4}\right)_{(2-n)}$ compounds}

The ${ }^{1} \mathrm{H}$ NMR of compounds $\mathbf{1 a}, \mathbf{1 b}$ and $\mathbf{1 c}$ were recorded at $298 \mathrm{~K}$ in dmso- $d_{6}$, dmso- $d_{6}$ and $\mathrm{CD}_{3} \mathrm{CN}$, respectively. In all three cases four sets of peaks were observed in the aromatic region. The hydrogen atoms present in the coordinated apy pyridine ring will be from now on referred to as NA, where $\mathrm{N}$ is a number that indicates the position of the hydrogen in the ring. Analogously, the hydrogen atoms in the non-coordinated
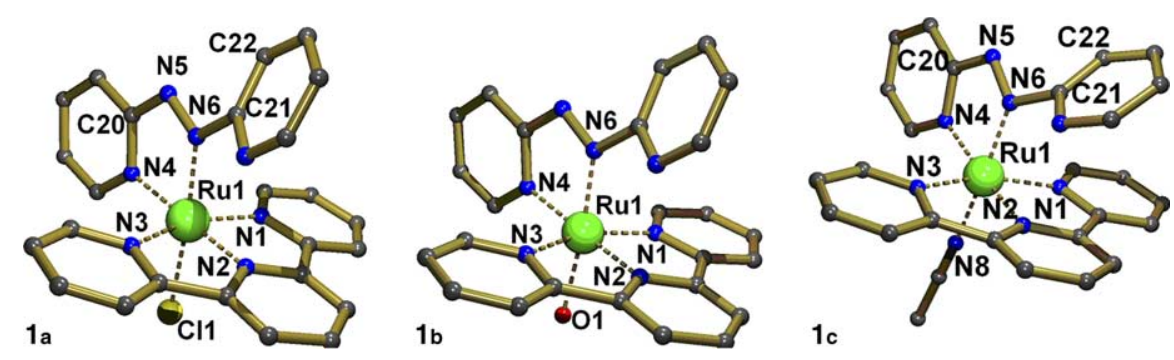

Fig. 1. PLATON projections of the cations $\left[\mathrm{Ru}^{\mathrm{II}}(\text { apy)(tpy) } \mathrm{L}]^{n+}\left(\mathrm{L}=\mathrm{Cl}, \mathrm{H}_{2} \mathrm{O}, \mathrm{CH}_{3} \mathrm{CN}\right)(\mathbf{1 a}-\mathbf{c})\right.$, with numbering of major atoms. Hydrogen atoms and counter ions have been omitted for clarity. 
Table 2

Selected distances $(\AA)$ and angles $\left({ }^{\circ}\right)$ in the crystal structures of $\left[\mathrm{Ru}\left(\right.\right.$ apy)(tpy)Cl] $\left(\mathrm{ClO}_{4}\right)(\mathbf{1 a}),\left[\mathrm{Ru}\left(\right.\right.$ apy)(tpy) $\left.\left(\mathrm{H}_{2} \mathrm{O}\right)\right]\left(\mathrm{ClO}_{4}\right)_{2} \cdot 2 \mathrm{H}_{2} \mathrm{O}(\mathbf{1 b})$ and $\left[\mathrm{Ru}(\right.$ apy $)($ tpy $\left.)\left(\mathrm{CH}_{3} \mathrm{CN}\right)\right]\left(\mathrm{ClO}_{4}\right)_{2}(\mathbf{1 c})$

\begin{tabular}{lr}
\hline Interatomic distances $(\AA)$ & \\
$\mathbf{1 a}$ & \\
$\mathrm{Ru}(1)-\mathrm{N}(1)$ & $2.060(3)$ \\
$\mathrm{Ru}(1)-\mathrm{N}(2)$ & $1.968(3)$ \\
$\mathrm{Ru}(1)-\mathrm{N}(3)$ & $2.074(3)$ \\
$\mathrm{Ru}(1)-\mathrm{N}(4)$ & $2.053(4)$ \\
$\mathrm{Ru}(1)-\mathrm{N}(6)$ & $1.981(3)$ \\
$\mathrm{Ru}(1)-\mathrm{Cl}(1)$ & $2.3962(9)$ \\
$\mathbf{1 b}$ & \\
$\mathrm{Ru}(1)-\mathrm{N}(1)$ & $2.075(2)$ \\
$\mathrm{Ru}(1)-\mathrm{N}(2)$ & $1.978(2)$ \\
$\mathrm{Ru}(1)-\mathrm{N}(3)$ & $2.066(2)$ \\
$\mathrm{Ru}(1)-\mathrm{N}(4)$ & $2.060(2)$ \\
$\mathrm{Ru}(1)-\mathrm{N}(6)$ & $1.960(2)$ \\
$\mathrm{Ru}(1)-\mathrm{O}(1)$ & $2.143(2)$ \\
$\mathrm{Hydrogen}$ bonds & \\
\hline $\mathrm{Donor}-\mathrm{H} \cdots$ Acceptor & $\mathrm{D} \cdots \mathrm{A}(\mathrm{A})$ \\
\hline $\mathrm{O}(1)-\mathrm{H}(101) \cdots \mathrm{O}(3)$ & $2.646(4)$ \\
$\mathrm{O}(1)-\mathrm{H}(102) \cdots \mathrm{O}(11)$ & $2.718(4)$ \\
$\mathrm{O}(2)-\mathrm{H}(103) \cdots \mathrm{O}(6)$ & $2.802(4)$ \\
$\mathrm{O}(2)-\mathrm{H}(104) \cdots \mathrm{O}(7)$ & $2.849(4)$ \\
$\mathrm{O}(3)-\mathrm{H}(105) \cdots \mathrm{O}(2)$ & $2.718(4)$ \\
$\mathrm{O}(3)-\mathrm{H}(106) \cdots \mathrm{O}(8)$ & $2.948(5)$ \\
$\mathbf{1 c}$ & \\
$\mathrm{Ru}(1)-\mathrm{N}(1)$ & $2.0710(18)$ \\
$\mathrm{Ru}(1)-\mathrm{N}(2)$ & $1.9833(19)$ \\
$\mathrm{Ru}(1)-\mathrm{N}(3)$ & $2.0762(18)$ \\
$\mathrm{Ru}(1)-\mathrm{N}(4)$ & $2.0512(19)$ \\
$\mathrm{Ru}(1)-\mathrm{N}(6)$ & $1.9744(18)$ \\
$\mathrm{Ru}(1)-\mathrm{N}(8)$ & $2.0537(19)$ \\
& \\
\hline &
\end{tabular}

Angles ( $\left.{ }^{\circ}\right)$

1a

$\mathrm{N}(4)-\mathrm{Ru}(1)-\mathrm{Cl}(1)$

$\mathrm{N}(4)-\mathrm{Ru}(1)-\mathrm{N}(6)$

$\mathrm{N}(4)-\mathrm{Ru}(1)-\mathrm{N}(1)$

$\mathrm{N}(4)-\mathrm{Ru}(1)-\mathrm{N}(2)$

$\mathrm{N}(4)-\mathrm{Ru}(1)-\mathrm{N}(3)$

$\mathrm{N}(6)-\mathrm{Ru}(1)-\mathrm{Cl}(1)$

$\mathrm{N}(6)-\mathrm{Ru}(1)-\mathrm{N}(1)$

$\mathrm{N}(6)-\mathrm{Ru}(1)-\mathrm{N}(2)$

$\mathrm{N}(6)-\mathrm{Ru}(1)-\mathrm{N}(3)$

$\mathrm{N}(1)-\mathrm{Ru}(1)-\mathrm{Cl}(1)$

$\mathrm{N}(1)-\mathrm{Ru}(1)-\mathrm{N}(2)$

$\mathrm{N}(1)-\mathrm{Ru}(1)-\mathrm{N}(3)$

$\mathrm{N}(2)-\mathrm{Ru}(1)-\mathrm{Cl}(1)$

$\mathrm{N}(2)-\mathrm{Ru}(1)-\mathrm{N}(3)$

$\mathrm{N}(3)-\mathrm{Ru}(1)-\mathrm{Cl}(1)$

$1 \mathrm{~b}$

$\mathrm{N}(4)-\mathrm{Ru}(1)-\mathrm{O}(1)$

$\mathrm{N}(4)-\mathrm{Ru}(1)-\mathrm{N}(6)$

$\mathrm{N}(4)-\mathrm{Ru}(1)-\mathrm{N}(1)$

$\mathrm{N}(4)-\mathrm{Ru}(1)-\mathrm{N}(2)$

$\mathrm{N}(4)-\mathrm{Ru}(1)-\mathrm{N}(3)$

$\mathrm{N}(6)-\mathrm{Ru}(1)-\mathrm{O}(1)$

$\mathrm{N}(6)-\mathrm{Ru}(1)-\mathrm{N}(1)$

$\mathrm{N}(6)-\mathrm{Ru}(1)-\mathrm{N}(2)$

$\mathrm{N}(6)-\mathrm{Ru}(1)-\mathrm{N}(3)$

$\mathrm{N}(1)-\mathrm{Ru}(1)-\mathrm{O}(1)$

$\mathrm{N}(1)-\mathrm{Ru}(1)-\mathrm{N}(2)$

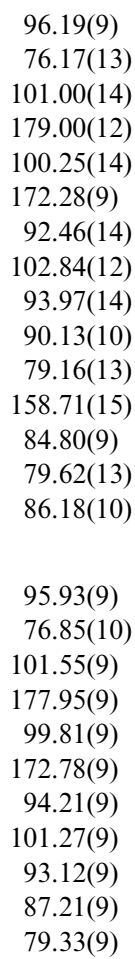

Table 2 (continued)

\begin{tabular}{lr}
\hline $\mathrm{N}(1)-\mathrm{Ru}(1)-\mathrm{N}(3)$ & $158.49(9)$ \\
$\mathrm{N}(2)-\mathrm{Ru}(1)-\mathrm{O}(1)$ & $85.95(9)$ \\
$\mathrm{N}(2)-\mathrm{Ru}(1)-\mathrm{N}(3)$ & $79.42(9)$ \\
$\mathrm{N}(3)-\mathrm{Ru}(1)-\mathrm{O}(1)$ & $88.05(9)$
\end{tabular}

$1 \mathrm{c}$

$\mathrm{N}(4)-\mathrm{Ru}(1)-\mathrm{N}(8)$

$\mathrm{N}(4)-\mathrm{Ru}(1)-\mathrm{N}(6)$

$\mathrm{N}(4)-\mathrm{Ru}(1)-\mathrm{N}(1)$

$\mathrm{N}(4)-\mathrm{Ru}(1)-\mathrm{N}(2) \quad 172.53(7)$

$\mathrm{N}(4)-\mathrm{Ru}(1)-\mathrm{N}(3)$

$\mathrm{N}(6)-\mathrm{Ru}(1)-\mathrm{N}(8)$

$\mathrm{N}(6)-\mathrm{Ru}(1)-\mathrm{N}(1)$

$\mathrm{N}(6)-\mathrm{Ru}(1)-\mathrm{N}(2)$

$\mathrm{N}(6)-\mathrm{Ru}(1)-\mathrm{N}(3)$

$\mathrm{N}(1)-\mathrm{Ru}(1)-\mathrm{N}(8) \quad 88.62(7)$

$\mathrm{N}(1)-\mathrm{Ru}(1)-\mathrm{N}(2) \quad 79.49(7)$

$\mathrm{N}(1)-\mathrm{Ru}(1)-\mathrm{N}(3) \quad 158.36(8)$

$\mathrm{N}(2)-\mathrm{Ru}(1)-\mathrm{N}(8)$

$\mathrm{N}(2)-\mathrm{Ru}(1)-\mathrm{N}(3) \quad 79.12(7)$

$\mathrm{N}(3)-\mathrm{Ru}(1)-\mathrm{N}(8)$

Torsion angles $\left({ }^{\circ}\right)$

1a

$\mathrm{N}(6)-\mathrm{N}(5)-\mathrm{C}(20)-\mathrm{N}(4) \quad-0.9(5)$

$\mathrm{N}(5)-\mathrm{N}(6)-\mathrm{C}(21)-\mathrm{C}(22) \quad-31.8(5)$

$1 \mathrm{~b}$

$\mathrm{N}(6)-\mathrm{N}(5)-\mathrm{C}(20)-\mathrm{N}(4)-1.3(4)$

$\mathrm{N}(5)-\mathrm{N}(6)-\mathrm{C}(21)-\mathrm{C}(22) \quad-29.6(4)$

$1 \mathrm{c}$

$\mathrm{N}(6)-\mathrm{N}(5)-\mathrm{C}(20)-\mathrm{N}(4)$

$\mathrm{N}(5)-\mathrm{N}(6)-\mathrm{C}(21)-\mathrm{C}(22)$

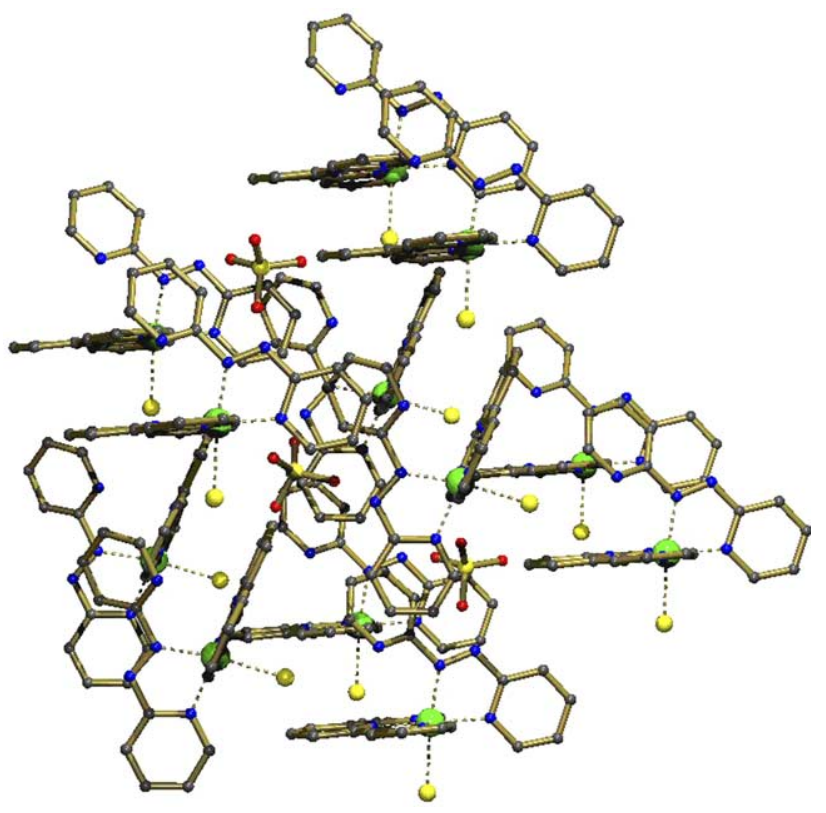

Fig. 2. Packing of $[\mathrm{Ru}(\mathrm{apy})(\mathrm{tpy}) \mathrm{Cl}]\left(\mathrm{ClO}_{4}\right)(\mathbf{1 a})$. Hydrogen atoms are omitted for clarity. 


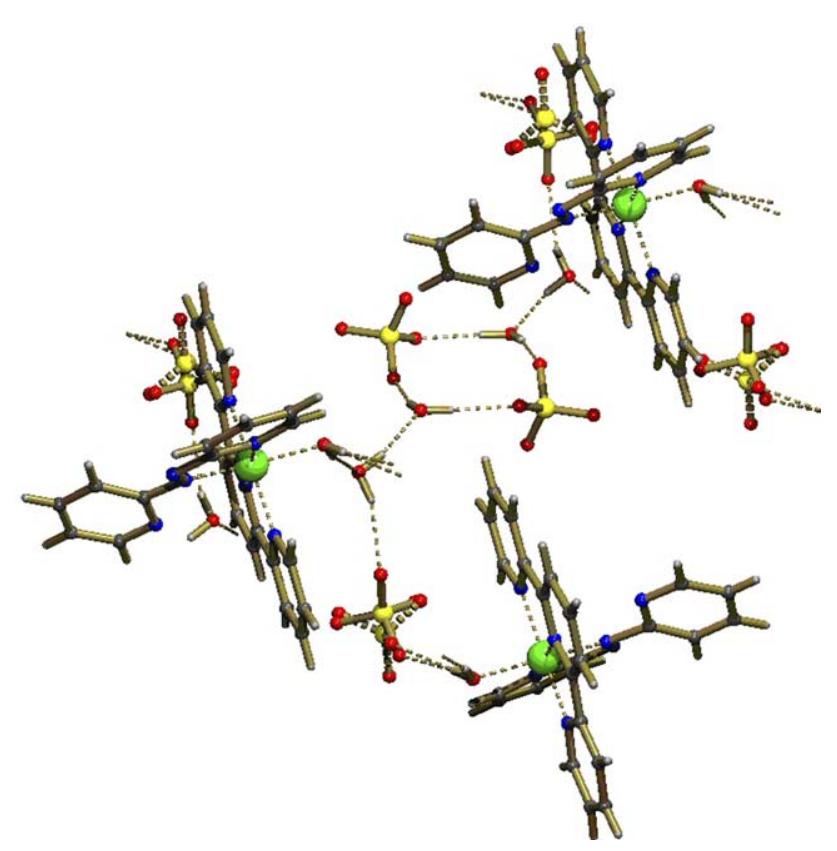

Fig. 3. Hydrogen bonding in $\left[\mathrm{Ru}(\right.$ apy $)($ tpy $\left.)\left(\mathrm{H}_{2} \mathrm{O}\right)\right]\left(\mathrm{ClO}_{4}\right)_{2} \cdot 2 \mathrm{H}_{2} \mathrm{O}(\mathbf{1 b})$.

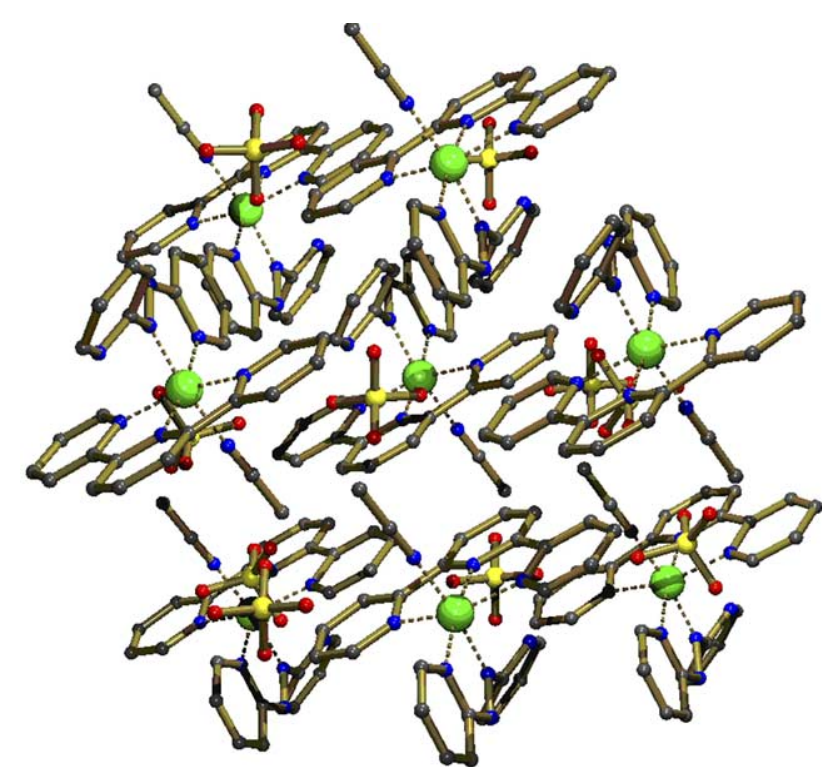

Fig. 4. Packing of $\left[\mathrm{Ru}\left(\right.\right.$ apy)(tpy) $\left.\left(\mathrm{CH}_{3} \mathrm{CN}\right)\right]\left(\mathrm{ClO}_{4}\right)_{2}$ (1c). Hydrogen atoms are omitted for clarity.

pyridine ring will be called NA'; the hydrogen atoms in the extreme pyridine rings in terpy, NT and finally the ones in the central pyridine ring in terpy, $\mathrm{NT}^{\prime}$ (see Fig. 5 for the numbering). The aromatic region of the ${ }^{1} \mathrm{H}-{ }^{1} \mathrm{H}$ COSY and NOESY spectra of 1a in dmso- $d_{6}$ at $298 \mathrm{~K}$ are shown in Fig. 6. Some assignments are indicated in the figure. The aromatic region of the ${ }^{1} \mathrm{H}-{ }^{1} \mathrm{H}$ COSY and NOESY spectra of $\mathbf{1 b}$ in dmso- $d_{6}$ and of 1c in $\mathrm{CD}_{3} \mathrm{CN}$ at $298 \mathrm{~K}$ are provided as supplementary information.

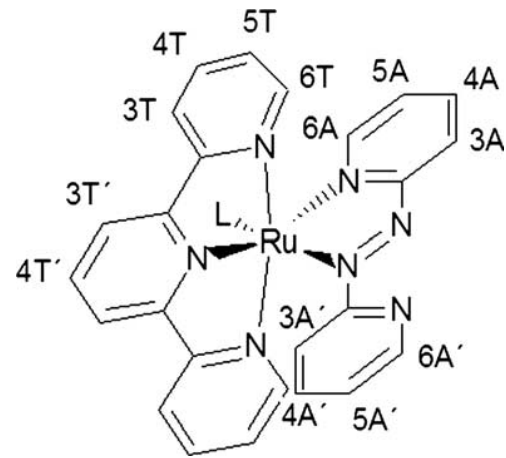

Fig. 5. $\left[\mathrm{Ru}(\right.$ apy $)($ tpy $\left.) \mathrm{L}^{n-}\right]\left(\mathrm{ClO}_{4}\right)_{(2-n)}$ compounds. Proton numbering scheme for ${ }^{1} \mathrm{H}$ NMR spectra.

The most deshielded peak in the aromatic region of the ${ }^{1} \mathrm{H}$ NMR spectrum of $1 \mathrm{a}$ appears at $9.83 \mathrm{ppm}$ and corresponds to the $6 \mathrm{~A}$ atom. This proton appears at such a low field, because it is close in space to a chlorine atom and also attached to a carbon adjacent to a coordinated nitrogen atom. This last fact determines that the $J$ coupling of this doublet is smaller than that of the one situated directly upfield, which can be assigned as $3 \mathrm{~A}$, as explained below. The 2D COSY connectivities result in the assignment of $5 \mathrm{~A}, 4 \mathrm{~A}$ and $3 \mathrm{~A}$, at $8.27,8.45$ and 8.93 ppm, respectively.

The 2D NOESY spectrum shows a clear crosspeak between the $6 \mathrm{~A}$ signal and that appearing at $7.22 \mathrm{ppm}$. Since it is known from the X-ray structure that $6 \mathrm{~A}$ and $6 \mathrm{~T}$ are close to each other in space, the signal al $7.22 \mathrm{ppm}$ is assigned to the $6 \mathrm{~T}$ atom. Once $6 \mathrm{~T}$ is known, $5 \mathrm{~T}, 4 \mathrm{~T}$ and $3 \mathrm{~T}$ can be assigned from the interactions shown in the COSY. Theoretically a NOESY peak should appear between $3 \mathrm{~T}$ and $3 \mathrm{~T}^{\prime}$, but this was not observed due to overlap. The set $6 \mathrm{~A}^{\prime}, 5 \mathrm{~A}^{\prime}, 4 \mathrm{~A}^{\prime}, 3 \mathrm{~A}^{\prime}$ appears much more upfield than $6 \mathrm{~A}, 5 \mathrm{~A}, 4 \mathrm{~A}, 3 \mathrm{~A}$ and can be assigned analogously. In this case, $6 \mathrm{~A}^{\prime}$ is also more deshielded than $3 \mathrm{~A}^{\prime}$.

The ${ }^{1} \mathrm{H}$ NMR spectra of $\mathbf{1 b}$ and $\mathbf{1 c}$ were assigned using the same methodology. The peaks corresponding to $3 \mathrm{~T}^{\prime}$ and $4 \mathrm{~T}^{\prime}$ appear overlapping those of $3 \mathrm{~T}$ and $5 \mathrm{~A}$, respectively, in the case of complexes $\mathbf{1 a}$ and $\mathbf{1 b}$. This can be seen from the integral values, as well as the COSY interactions. In the spectrum of $\mathbf{1 c}$ the signals corresponding to $3 \mathrm{~T}^{\prime}, 4 \mathrm{~T}^{\prime}$ and $3 \mathrm{~T}$ are overlapped, forming a multiplet of intensity four.

The peak corresponding to $5 \mathrm{~A}^{\prime}$ in complex $\mathbf{1 b}$ overlaps with $6 \mathrm{~T} ; 3 \mathrm{~A}^{\prime}$ and $5 \mathrm{~A}^{\prime}$ are overlapping with each other in complex 1c, resulting in a multiplet of intensity two. The chemical shift values of all the above-mentioned protons are listed in Table 3.

\section{Concluding remarks}

A family of ruthenium polypyridyl compounds of structural formula $\left[\mathrm{Ru}(\mathrm{apy})(\mathrm{tpy}) \mathrm{L}^{n-}\right]\left(\mathrm{ClO}_{4}\right)_{(2-n)}$ 

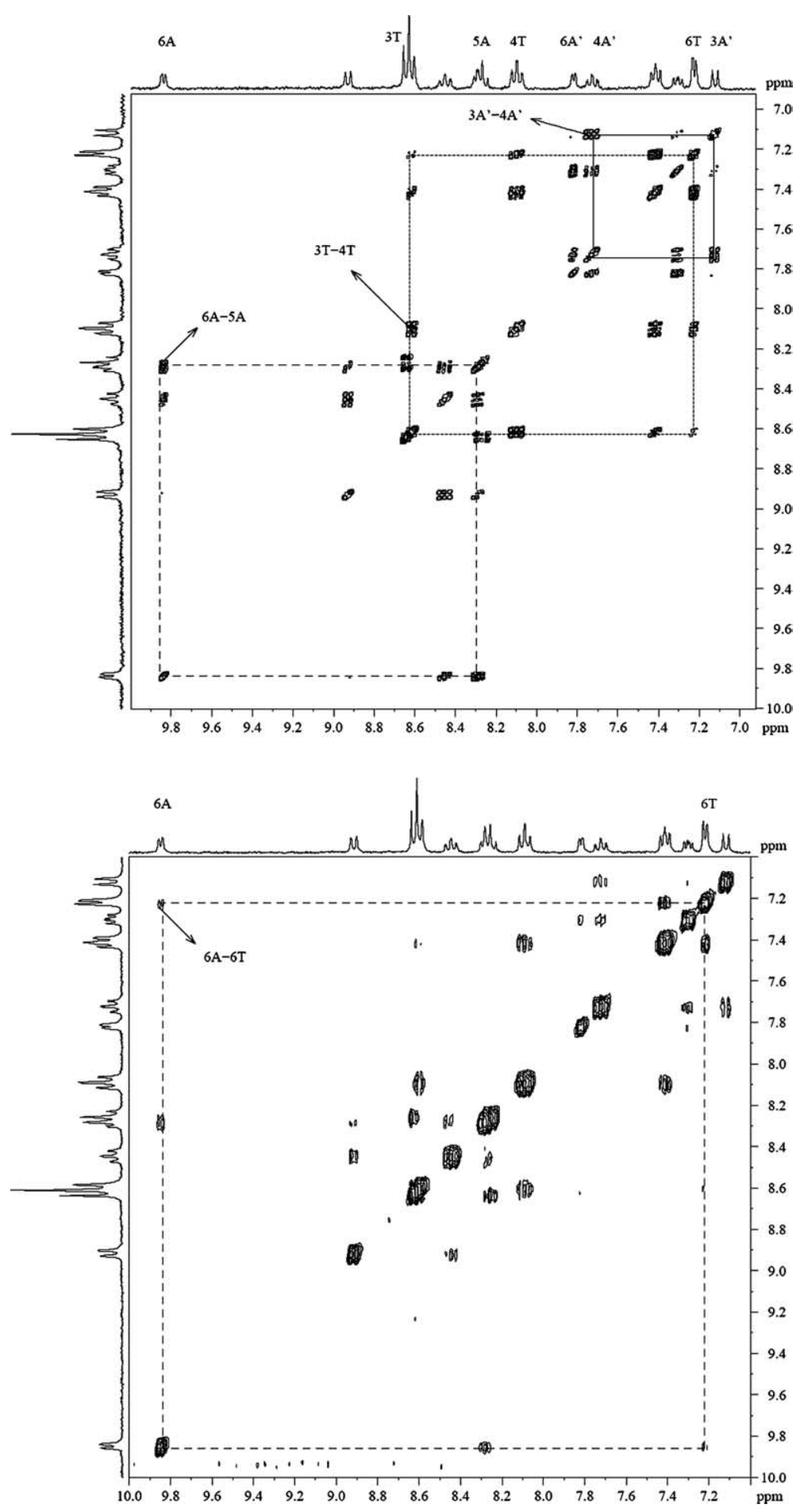

Fig. 6. Aromatic region of the ${ }^{1} \mathrm{H}-{ }^{1} \mathrm{H}$ COSY (above) and NOESY (below) spectra of 1a in dmso- $d_{6}$ at $298 \mathrm{~K}$, with some assignments. In the COSY spectrum, the dashed lines indicate the 6A-5A(-4A-3A) COSY cross peaks. The dotted lines show the 3T-4T(-5T-6T) COSY cross peaks. The solid

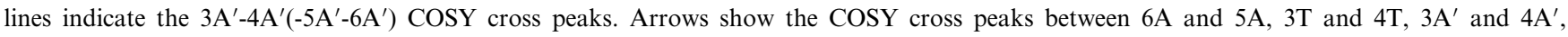
respectively. In the NOESY spectrum, the $6 \mathrm{~A}-6 \mathrm{~T}$ NOEs are signalled.

(apy $=2,2^{\prime}$-azobispyridine; tpy $=2,2^{\prime}: 6^{\prime}, 2^{\prime \prime}$-terpyridine; $\left.\mathrm{L}=\mathrm{Cl}, \mathrm{H}_{2} \mathrm{O}, \mathrm{CH}_{3} \mathrm{CN}\right)(\mathbf{1 a}-\mathbf{c})$ was successfully synthesized and characterized. The study of their crystal structures revealed trans azo-nitrogen coordination similar to that reported for 2-phenylazopyridine, and $\pi-\pi$ stacking between the pyridine rings.

The potential interest of these complexes is multiple. They have been designed to be analogous to $\mathrm{Ru}(\mathrm{tpy}) \mathrm{Cl}_{3}$, 
Table 3

Proton chemical shift values $(\mathrm{ppm})$ for the $\left[\mathrm{Ru}(\mathrm{apy})(\mathrm{tpy}) \mathrm{L}^{n-}\right]\left(\mathrm{ClO}_{4}\right)_{(2-n)}$ complexes $\mathbf{1 a}-\mathbf{1 c}$. $\mathbf{1 a}$ and $\mathbf{1 b}$ were taken in dmso- $d_{6}$; $\mathbf{1 c}$ was taken in $\mathrm{CD}{ }_{3} \mathrm{CN}$, all of them at $298 \mathrm{~K}$

\begin{tabular}{|c|c|c|c|c|c|c|c|c|c|c|c|c|c|c|}
\hline \multirow[t]{2}{*}{ Complex } & \multicolumn{14}{|c|}{ Proton } \\
\hline & $3 \mathrm{~A}$ & $4 \mathrm{~A}$ & $5 \mathrm{~A}$ & $6 \mathrm{~A}$ & $3 \mathrm{~A}^{\prime}$ & $4 \mathrm{~A}^{\prime}$ & $5 \mathrm{~A}^{\prime}$ & $6 \mathrm{~A}^{\prime}$ & $3 \mathrm{~T}$ & $4 \mathrm{~T}$ & $5 \mathrm{~T}$ & $6 \mathrm{~T}$ & $3 \mathrm{~T}^{\prime}$ & $4 \mathrm{~T}^{\prime}$ \\
\hline $1 \mathrm{a}$ & 8.93 & 8.45 & 8.27 & 9.83 & 7.12 & 7.72 & 7.31 & 7.82 & 8.63 & 8.10 & 7.41 & 7.22 & 8.63 & 8.27 \\
\hline $1 b$ & 9.01 & 8.55 & 8.36 & 9.46 & 7.14 & 7.75 & 7.34 & 7.84 & 8.67 & 8.19 & 7.50 & 7.34 & 8.67 & 8.36 \\
\hline 1c & 8.93 & 8.50 & 8.18 & 9.67 & 7.27 & 7.70 & 7.27 & 7.80 & 8.38 & 8.06 & 7.36 & 7.36 & 8.38 & 8.38 \\
\hline
\end{tabular}

a compound with anticancer activity, but with the disadvantage of a poor water-solubility. The $\left[\mathrm{Ru}\left(\right.\right.$ apy)(tpy) $\left.\mathrm{L}^{n-}\right]\left(\mathrm{ClO}_{4}\right)_{(2-n)}$ complexes show an improved solubility. Moreover the ligand apy is structurally related to azpy, which is present in recently reported cytotoxic ruthenium complexes [3,4]. Therefore it is of interest to find out how these compounds interact with DNA model bases and DNA, since the anticancer properties of a number of platinum and ruthenium complexes are generally accepted to be related to their binding to the DNA of cancerous cells [1]. In a subsequent study a series of both cisplatin-resistant and non-resistant cancerous cell lines will be treated with the $\left[\mathrm{Ru}(\right.$ apy $)($ tpy $\left.) \mathrm{L}^{n-}\right]\left(\mathrm{ClO}_{4}\right)_{(2-n)}$ complexes to test factors, such as the cellular uptake and the anticancer activity of such compounds.

\section{Acknowledgments}

The support and sponsorship concerted by COST Actions D20/0001/00, D20/0002/00 and D20/003/01 is kindly acknowledged. This work has been performed under the auspices of the joint BIOMAC Research Graduate School of Leiden University and Delft University of Technology. We thank the Council for the Chemical Sciences of the Netherlands Organisation for Scientific Research (CW-NWO) for their support. The authors thank Johnson \& Matthey (Reading, UK) for their generous loan of $\mathrm{RuCl}_{3} \cdot 3 \mathrm{H}_{2} \mathrm{O}$.

\section{Appendix A. Supplementary data}

Crystallographic data (excluding structure factors) for the structures reported in this paper have been deposited at the Cambridge Crystallographic Data Centre as numbers CCDC 266695-266697.

Copies of the data can be obtained free of charge on application to The Director, CCDC, 12 Union Road, Cambridge CB2 1EZ, UK (fax: +044 1223 336033; e-mail: deposit@chemcrys.cam.ac.uk). Supplementary data associated with this article can be found, in the online version, at doi:10.1016/j.ica.2005.05.017.

\section{References}

[1] J. Reedijk, Proc. Natl. Acad. Sci. USA 100 (7) (2003) 3611.

[2] O. Novakova, J. Kasparkova, O. Vrana, P.M. Vanvliet, J. Reedijk, V. Brabec, Biochemistry 34 (38) (1995) 12369.

[3] A.C.G. Hotze, S.E. Caspers, D. de Vos, H. Kooijman, A.L. Spek, A. Flamigni, M. Bacac, G. Sava, J.G. Haasnoot, J. Reedijk, J. Biol. Inorg. Chem. 9 (3) (2004) 354.

[4] A.H. Velders, H. Kooijman, A.L. Spek, J.G. Haasnoot, D. de Vos, J. Reedijk, Inorg. Chem. 39 (14) (2000) 2966.

[5] L. Mishra, A.K. Yadaw, R. Sinha, A.K. Singh, Indian J. Chem., Sect. A 40 (9) (2001) 913.

[6] G. Sava, K. Clerici, I. Capozzi, M. Cocchietto, R. Gagliardi, E. Alessio, G. Mestroni, A. Perbellini, Anti-Cancer Drugs 10 (1) (1999) 129.

[7] G. Sava, S. Pacor, A. Bergamo, M. Cocchietto, G. Mestroni, E. Alessio, Chem.-Biol. Interact. 95 (1-2) (1995) 109.

[8] A. Kirpal, E. Reiter, Ber. Deut. Chem. Ges. 60B (1927) 664.

[9] W. Kaim, Coord. Chem. Rev. 219 (2001) 463.

[10] N.C. Pramanik, K. Pramanik, P. Ghosh, S. Bhattacharya, Polyhedron 17 (9) (1998) 1525.

[11] K. Hansongnern, U. Saeteaw, G. Mostafa, Y.C. Jiang, T.H. Lu, Anal. Sci. 17 (5) (2001) 683.

[12] K.J. Takeuchi, M.S. Thompson, D.W. Pipes, T.J. Meyer, Inorg. Chem. 23 (13) (1984) 1845.

[13] B. Mondal, M.G. Walawalkar, G.K. Lahiri, J. Chem. Soc., Dalton Trans. (22) (2000) 4209.

[14] F. Laurent, E. Plantalech, B. Donnadieu, A. Jimenez, F. Hernandez, M. Martinez-Ripoll, M. Biner, A. Llobet, Polyhedron 18 (25) (1999) 3321.

[15] P.A. Adcock, F.R. Keene, R.S. Smythe, M.R. Snow, Inorg. Chem. 23 (15) (1984) 2336.

[16] R.H. Blessing, Acta Crystallogr., Sect. A 51 (1995) 33.

[17] G.M. Sheldrick, SADABS. Program for Empirical Absorption Correction, Bruker AXS, Karlsruhe, Germany, 2004.

[18] P.T. Beurskens, G. Beurskens, R. de Gelder, S. Garcia-Granda, R.O. Gould, R. Israel, J.M.M. Smits, The DIRDIF-99 Program System, Crystallography Laboratory, University of Nijmegen, The Netherlands, 1999.

[19] G.M. Sheldrick, SHELXL97. Program for Crystal Structure Refinement, University of Göttingen, Germany, 1997.

[20] A.L. Spek, J. Appl. Crystallogr. 36 (2003) 7.

[21] S. Goswami, A.R. Chakravarty, A. Chakravorty, Inorg. Chem. 21 (7) (1982) 2737. 